\title{
Research on the Right of Innocent Passage in the Territorial Waters
}

\author{
Shihao Yang \\ International Law, East China University of Political Science and Law, Lichuan, Hubei, China
}

\begin{abstract}
This article takes the relevant legal system of innocent passage in the territorial waters in international law as the research object, combines the knowledge of jurisprudence, comprehensively uses comparative analysis, historical analysis, and law hermeneutics. Based on an in-depth analysis of the innocent passage system, the relevant practices and positions of various countries about the innocent passage system in territorial waters are summarized, and various issues such as whether innocent passage system in territorial waters is applicable to the warships are discussed. And analyzes China's current position and practice on innocent passage system, and then put forward suggestions for improvement.
\end{abstract}

Keywords: Innocent passage through the territorial waters, United Nations convention on the law of the sea, Rights and obligations of the coastal State.

\section{Introduction}

The system of innocent passage is of great practical significance to the order of navigation, the utilization of ocean and the protection of state power. In this paper, the study of innocent passage system has the following significance: First, it is conducive to a deeper understanding of the relevant systems and provisions of international law relating to maritime navigation, the understanding of innocent passage system, and the understanding of other systems of international law of the sea such as transit system. Secondly, it is conducive to safeguarding the navigation rights and sovereignty of sovereign states. Ships of various countries can also protect their legitimate interests from being infringed by coastal states that abuse rules and systems through innocent passage. Finally, it is beneficial for coastal states to make reasonable use of the system to protect national interests and sovereignty from infringement.

\section{The Concept and Legal Elements of the Right of Innocent Passage}

\subsection{The Concept of the Right of Innocent Passage}

Innocent passage is a very old international legal system with a history of several hundred years. As early as the 17th and 18th centuries, there was a concept of "innocent use of territorial waters". For example, Grotius in the 17th century believed that coastal states could not interfere with "navigation without arms and with no intention of harm". Henry Wheaton of the 18th century argued that the "innocence use" of other persons should be allowed so long as it does not cause harm to the owner or other unreasonable conditions; It is also defined in the Oppenheim International Law to mean navigation through the territorial sea of a coastal State without entering its internal waters, including navigation through the territorial sea for the purpose of sailing towards or out of its internal waters.

With the deepening of world development and globalization, the right of innocent passage stipulated by modern international law is a vessel passage system applicable to the territorial waters of coastal states stipulated by the United
Nations Convention on the Law of the Sea. Specifically, it means that a coastal state, on the basis of the convenience and safety of international navigation, allows vessels of other countries to pass through its territorial sea without harming its own peace, security and good order. However, if the vessels of other countries cause interference to its sovereignty in the process of passage, the coastal state has the right to take relevant measures to safeguard its sovereignty.

\subsection{The Legal Elements of the Right of Innocent Passage}

Innocent passage is an extension of the principle of customary international law of freedom of the seas, which is stipulated in the 1958 Convention on the Territorial Sea and Adjacent Zones, the 1982 United Nations Convention on the Law of the Sea (UNCLOS) and modern international law. The right of innocent passage is a strict navigation system, and its strictness is reflected in various restrictions on foreign ships in many aspects. The right of innocent passage, as it literally means, has two most important legal requirements for its establishment, namely "innocent" and "passage".

First of all, article 18 of the UNCLOS provides for the constituent elements of passage. Paragraph 1 provides for the first requirement of passage, which can be interpreted in three ways :(1) simply crossing the territorial sea of the coastal state without entering its internal waters or docking at moorings or port facilities other than its internal waters; (2) from the internal waters of the coastal State or from the birth of the coastal State; (3) Entering or docking at moorings or port facilities in or beyond the internal waters of the coastal State. Paragraph 2 sets out the second requirement for "adoption", consisting of the requirement of expediency and continuity. By including anchors and stopping the ship, usually with the incidental and force majeure, salvage, as for the definition of "rapid", should be combined with the ship's various aspects of the specific situation, such as the size of the ship, performance to determine.

Secondly, the constitution of "innocent Passage" is stipulated in Article 19 of the UNCLOS, so as to fully protect the security and sovereignty of the coastal States. Paragraph 1 stipulates that "innocent passage" means passage without prejudice to the peace, security and good order of the coastal 
States. In conformity with other provisions of UNCLOS and other international practices, customs and rules; Paragraph 2 also defines, by way of example, 12 typical "harmful" behaviors (i.e., "non-innocent") covering a wide range of areas, including the security and sovereign interests of the coastal State, such as customs, finance, immigration, health, scientific research and fishing.

Through the provisions of articles 18 and 19 of UNCLOS, we can have a deeper and clearer understanding of the legal elements of innocent passage. The Constitution of "passage" and "innocent passage" can be legislated separately in the UNCLOS, which can be distinguished from the way in which UNCLOS on the Territorial Sea and the Contiguous Zone provides them in the same article. At this point, if an act is not in conformity with article 18 of UNCLOS, the provisions of either article 19, paragraph 1, or article 19, paragraph 2, of UNCLOS may be applied[1].

\section{The Connotation of the Right of Innocent Passage in Territorial Sea}

\subsection{Applicable Objects for Innocent Passage}

Article 17 of UNCLOS provides that, under this provision, "ships" of any State shall enjoy the right of innocent passage. The reason for the establishment of a system of innocent passage in UNCLOS is to balance and harmonize the sovereignty of coastal States and the navigation interests of foreign vessels. As an international right, the system is a compromise product. In a long time after the formation of the system of international intercourse, foreign merchant in the coastal countries' territorial waters have innocent passage has long been without controversy, all countries have been determined by legislation and the practice of foreign merchant is the rights, but about whether the warship shall enjoy the right of innocent passage, has long been controversial.

Scholars who hold negative opinions hold that the right of innocent passage of warships is related to national sovereignty and should be explicitly stipulated, but article 17 of UNCLOS has no explicit stipulation. At the same time, it is widely believed by the international community that warships are potentially harmful, so they should not enjoy the right of innocent passage of territorial sea.

Scholars who hold positive views hold that the term "ship" used in Article 17 of UNCLOS does not clearly distinguish between the nature of ships, which should be understood in the usual sense, namely, both warships and merchant ships. In addition, according to the provisions of Article 19 of UNCLOS, ships shall not "exercise weapons" or "launch, land or pick up aircraft on board the ship" when passing, indicating that UNCLOS does not exclude military vessels from the application of the right of innocent passage, since only military vessels can engage in these two acts. Thirdly, article 20 of UNCLOS stipulates the manner of innocent passage by submarine, indicating that the innocent passage stipulated in UNCLOS applies to not only merchant ships, but also naval vessels, including submarines. Therefore, warships have the right of innocent passage through the territorial sea. Most Chinese scholars, such as Zhou Gengsheng and Li Hongyun, also believe that the innocent passage system can be applied to warships. Professor Li Hongyun also made a detailed summary of this in "On the Right of Innocent Passage of Foreign Warships in the Territorial Sea"[2].

The classic case of the International Court of Justice, the Corfu Channel case, can help us to have a better understanding of whether the innocent passage system applies to warships. The main facts of the case are that British warships passed through the Corfu Channel at three different times for different purposes of navigation, and there was a dispute with Albania over the innocent passage of the warships. The International Court of Justice also made different judgments on these three warship voyages. The first was in May 1946, when two British warships were bombarded by Albanians as they passed through the Corfu Strait, which the British considered a violation of their right to innocent passage through the international straits. The second time was in October of the same year, in order to test Albania, Britain sent four warships through the Corfu Channel, which hit a underwater mine in Albania and suffered great damage. The third time was in November of the same year, with the purpose of removing underwater mines in Albania and collecting evidence of Albanian illegal activities, Britain again passed through the Corfu Channel and part of the Territorial waters of Albania, and finally cleared 22 underwater mines. For the first two British warships through, the international court of justice was identified as the "innocent passage", because, according to the international practice, allow warships innocent passage through international channel, this kind of "innocent", only needs to be "seemingly harmless" and "pass-through innocent". (Although the purpose of the second British warship passage seemed "non-innocent"). For the third time the British warships, the international court of justice to do is different from the previous two judgements, think the purpose of the British warships sailing is to mine, "its legitimacy is unable to use harmless by showing that", according to the regulation of international law, foreign warships in conditions shall not be permitted in conduct the behavior within a country's territorial waters. It can be seen that the international Court of Justice did not adopt the same reasoning methods from the different judgments of the Three times on the passage of the British warship. It also held that the passage of the British warship for the third time violated the sovereignty of Albania. The international Court of Justice's ruling has also aroused discussions among international law scholars on whether the right of innocent passage in territorial waters can be applied to warships and how it should be applied. In any case, the ICJ's decision, which clarifies the right of foreign ships to sail at sea, is bound to have a far-reaching impact on the navigation of warships.

In fact, these two differences of opinion have existed since the conclusion of UNCLOS. For example, in 1973, when some developing countries submitted draft articles, they asked for permission or prior notice of warships passing through the territorial waters of coastal states, but this was strongly opposed by the UK, the US, France and other countries. UNCLOS does not stipulate whether innocent passage applies to warships, and different countries have different legislation and practices in response to the defects of this system. At present, 106 states out of 152 coastal States and regions have the right to innocent passage of warships without prior 
permission or notice. Forty-two countries set conditions for notification or permission (30 require approval and 12 require prior notification). In my view, at the present time, the right of innocent passage of a warship in the territorial waters of a State should be clearly defined on the basis of its special nature and legal status as distinct from that of other ordinary ships. First of all, as an important part of a country's armed forces, warships can carry aircraft, missiles and weapons of mass destruction, posing a threat to the coastal states themselves and theoretically not necessarily meeting the requirements for innocent passage. Secondly, the original intention of innocent passage is to facilitate merchant trade, not the passage of warships. Moreover, 42 countries in the international community have stipulated that the innocent passage of warships must be approved or notified in advance by the coastal State. This shows that the innocent passage of warships has not yet formed a universally recognized international custom. If the innocent passage of warships is not explicitly stipulated, conflicts and conflicts are bound to arise.

\subsection{Extent of Territorial Sea}

As early as 1702, Binkshuk, a French jurist, proposed the "cannon range rule" for measuring the width of the territorial sea, that is, taking the range of coastal cannons as the width of the territorial sea. However, as Oppenheim International Law states, although the Shuker rule can determine that a certain area of waters is under the sovereignty of the coastal State, the territorial sea width determined by this rule is not uniform due to the objective fact that the artillery range is increasing.

After that, The Hague Conference in 1930 and the two ocean conferences in 1958 and 1960 failed to reach a consensus on the extent of territorial waters, which was one of the reasons for the third Conference on the Law of the Sea. Article 2 of UNCLOS explains the definition of territorial sea, which refers to the maritime area adjacent to the state sovereignty of a coastal State beyond its internal waters. This sovereignty extends not only to the seabed and subsoil of the territorial sea, but also to the airspace over the territorial sea. This provision inherits the content of the first two articles of UNCLOS on the Territorial Sea and the Contiguous Zone, and at the same time clearly reflects the view that the territorial sea is an integral part of the coastal State. Article 3 of UNCLOS provides for the limits of the territorial sea, which can be determined by the coastal State at its discretion until the base line established by UNCLOS does not exceed 12 nautical miles, that is, 12 nautical miles is the maximum width of the territorial sea. This provision makes up for the lack of provisions on the scope of territorial sea in UNCLOS on the Territorial Sea namely the Contiguous Zone, and creates conditions for determining the scope of contiguous zone and exclusive economic zone.

On the basis that the width of territorial sea as stipulated in UNCLOS should not exceed 12 nautical miles, China maintains that the extent of territorial sea should be reasonably determined by each State in light of its own needs. At the same time, China has supported other countries' claims to expand their territorial waters, such as Indonesia's 1957 extension of its territorial waters from three nautical miles to 12 nautical miles.

\subsection{Comparison of Innocent Passage System and Other Passage Systems}

\subsubsection{Comparison with Freedom of Navigation System}

Innocent passage in the territorial water is different from the high seas freedom of navigation system. Because of the high seas does not belong to any sovereign state, all countries have the right to use the high seas, so any vessel of any country has the right to sail on the high seas without restrictions from any other country. There are many differences between innocent passage system and freedom of navigation system, mainly reflected in the following aspects:

First of all, the applicable object is different. As mentioned above, innocent passage applies only to ships (whether it is applicable to warships is controversial in the international community), and not to aircraft. The scope of the freedom of navigation system is much broader, not only applies to all kinds of ships of all countries (including warships and non-warships), aircraft and other aircraft are also applicable to the freedom of navigation system, can fly over the high seas.

Secondly, the scope of application is different. The innocent passage applies within the territorial sea of the coastal State, as well as to internal waters obtained using straight baselines, archipelagic waters other than the internal waters of the archipelago and some channels used for international navigation, whereas the regime of freedom of navigation of the high seas applies only to the area of the high seas.

What's more, the meaning is different. As mentioned above, there are two core elements of the innocent passage system, namely "passage" and "harmless", while the freedom of navigation system does not have such requirements. UNCLOS only requires ships of sovereign States to take due account of the maritime interests and navigation rights of other states when sailing on the high seas.

Finally, coastal states have different rights. In the innocent passage system, sovereign states can exercise certain jurisdiction, protection and management over foreign ships passing through their territorial waters, while in the freedom of navigation system, ships of other countries are not under the jurisdiction of coastal states, but only under the jurisdiction of flag States.

\subsubsection{Comparison with Transit System}

The transit system is not as old as the freedom of navigation system. It is a new system established by the THIRD United Nations Conference on the Law of the Sea to protect the right of passage of states in some special maritime areas. The difference between the innocent passage system and the transit system is mainly reflected in the following aspects:

First of all, the applicable object is different. As mentioned above, the innocent passage system only applies to ships above the surface of the water (whether it applies to warships is debatable), excluding aircraft such as aircraft, and submersibles such as submarines, which need to show the national flag to enjoy the right of innocent passage. The transit system, which applies to all ships (warship and non-warship), also allows aircraft to fly over, and submersibles such as 
submarines to pass through underwater. Vessels, aircraft and aircraft exercising the right of passage in transit shall comply with the provisions of UNCLOS and other international practices and rules and regulations.

Secondly, the scope of application is different. The innocent passage system is not only applicable to the territorial sea of the coastal State, but also to some special waters, not to the airspace over the territorial sea. The transit system applies not only to the surface of the water, but also to the overlying water and its airspace.

What's more, the meaning is different. The core of the innocent passage system is "passage" and "innocent", but the transit passage system is different from it, and is different from the freedom of navigation system. Foreign ships and aircraft are required to stop the passage quickly, and are not allowed to engage in any activities other than passage, except under the circumstances of force majeure and salvage at sea.

Finally, the coastal States have different rights. Under the innocent passage system, the coastal States may formulate relevant laws and regulations concerning maritime traffic, fishery, various resources at the bottom of the sea and navigation safety, etc., and may designate channels for foreign vessels or apply the navigation separation system when necessary. Under the system of transit, the straits coastal States enjoy sovereignty over and exercise jurisdiction over the waters, seabed, subsoil and airspace of the waters, and foreign vessels and aircraft cannot influence the legal status of those waters. Coastal States may formulate relevant laws and regulations to protect their own customs, finance, immigration and health.

\section{Rights and Obligations of Coastal States under the System of Innocent Passage of Territorial Sea}

\subsection{Rights of Coastal States}

Section iii of Part II of UNCLOS specifies in detail the rights and obligations of the coastal State in the innocent passage regime. It is necessary to make a detailed division of these rights and obligations.

\subsubsection{Legislative Jurisdiction}

The territorial sea is an extremely important part of the territory of a sovereign State. The coastal State has sovereignty over the waters, seabed, subsoil, economic resources and airspace of its territorial sea and therefore, of course, has legislative jurisdiction and the right to enact laws and regulations applicable to the territorial sea.

In 1958, the Convention on the Territorial Sea and the Contiguous Zone stipulates that foreign vessels, when exercising the right of innocent passage, shall respect and obey the laws and regulations formulated by the coastal States, especially those relating to maritime navigation. There is no doubt that the regulation makes it clear that foreign vessels should comply with the laws of the coastal State, but it does not explicitly limit the legislative jurisdiction of the coastal State. Therefore, in practice, the coastal State actually enjoys great discretion, resulting in regulations that restrict or even deprive foreign vessels of their right to innocent passage. The provisions of the 1982 UNCLOS changed the situation: it specified in detail the matters for the coastal State to enact relevant laws and regulations, but in fact restricted the legislative direction of the coastal State. Article 21, paragraph 1 , of UNCLOS identifies, by enumeration, eight situations in which coastal States may enact laws and regulations. Including maintenance of navigation safety and traffic management, related regulations about the protection of the equipment and facilities, such as specific measures for protection of cable pipe, how biological resources conservation and development, and protection of fishery prevent overfishing, prevent Marine environment pollution and protect the ecological, scientific research and hydrological measurement issues related to financial immigration health, customs, etc., in addition, Coastal States may also enact relevant regulations in accordance with the provisions of UNCLOS and other rules of international law. According to the above provisions, the enactment of laws and regulations by coastal States should be done within the framework of UNCLOS and the rules of international law, which in practice limits the right of coastal States to enact regulations. Article 21, paragraph 4, of UNCLOS only provides that foreign vessels shall comply with the relevant laws and regulations of the coastal State in their innocent passage through the territorial sea of the coastal State, but does not specify what consequences they will bear if they violate the laws and regulations of the coastal State. This means that the coastal State may take all measures provided for in its national laws and regulations to prevent and avoid violations of the relevant laws and regulations by foreign vessels, provided that the innocent passage of foreign vessels is not impeded; In addition, if a foreign ship fails to comply with the laws and regulations of a sovereign state in the territorial waters of a coastal state, and then flees the territorial waters of a coastal state, the coastal state can exercise the right to pursue it.

Article 21, paragraph 2, of UNCLOS provides that the legislative jurisdiction of the coastal State shall be limited to a certain extent and that such legal regulations "shall not apply to the design, construction, manning or equipping of foreign vessels". The exception is that they may apply if they "give effect to generally accepted international rules or standards". This provision, in fact, reflects a general principle in UNCLOS, namely, to avoid problems arising from different national provisions and to protect the consistency of maritime rules worldwide. Has a strong international ocean shipping, the generally accepted international rules and standards deserve countries abide by ship, if a country's laws and regulations can be involved in the design of the ships of another country, personnel, equipped with, etc., so innocent passage of foreign vessels in practice may be limited because of the coastal state laws, regulations or deprivation.

\subsubsection{Judicial Jurisdiction}

As mentioned above, the territorial sea is an extremely important part of a State's territory and therefore the State has legislative jurisdiction over it and certainly has judicial jurisdiction over it. The state exercises jurisdiction over 
relevant areas based on the protection of its vital interests, including the guarantee of national boundaries and security, management of Marine resources, exploitation of fishing and so on. After all, territorial waters are different from land territories, and the jurisdiction of the coastal State is limited by the right of innocent passage. Moreover, the coastal State is expected to respect the foreign jurisdiction over its own vessels. It should be noted that, as noted above, military vessels are different in nature from and have a different legal status from merchant vessels. They enjoy immunity while navigating, so the coastal State does not have the right to exercise jurisdiction over foreign warships. Therefore, ships discussed in this Section do not include military vessels.

First of all, the coastal state has criminal jurisdiction. If foreign vessels, while passing through the territorial waters of the coastal State, engage in acts of piracy, smuggling of immigrants, illegal fishing, illegal dumping and other acts that impair the peace, security and good order of the coastal State, the coastal State shall have the right to stop such acts, but it does not have jurisdiction over other ordinary criminal cases on board, but it does not have jurisdiction over other ordinary criminal cases on board. Jurisdiction is based on the sovereignty of a State, but this does not mean that a State can exercise jurisdiction under any circumstances on the grounds of sovereignty. Although the territorial sea is the territory of a state, it is indeed different from land, and the right of innocent passage also has an important impact on the jurisdiction of the coastal State.

The flag of a ship can explain the relationship between the ship and its state, but not its judicial nature. If the flag State has jurisdiction over the ship, this right is mainly reflected in administrative and technical aspects. For criminal cases on board, the flag State's jurisdiction is not generally effective. When a ship is located in the territorial sea of the coastal state, the jurisdiction of the two countries may conflict. According to the principle of territorial jurisdiction priority, the jurisdiction of the coastal state usually has the priority status.

Secondly, the coastal State has civil jurisdiction. This is provided for in the Convention on the Territorial Sea and the Contiguous Zone and UNCLOS, in articles 20 and 28 respectively. The coastal State may detain or enforce a foreign ship under two circumstances: 1) A foreign ship stays in the territorial sea of the coastal State or enters the territorial sea from its coastal domestic waters; 2) Foreign ships shall be liable or have obligations due to collision, accident or other causes during navigation. Except in these two cases, the coastal State does not exercise civil jurisdiction in ordinary cases; In terms of prevention and control of pollution, UNCLOS places the responsibility on all States to prevent pollution of the sea, with the flag State and coastal state having jurisdiction if pollution is caused. In particular, the coastal State may detain a foreign ship and initiate judicial proceedings if there is evidence that the foreign ship has caused pollution in its exclusive economic zone and caused damage to the coastal State.

\subsubsection{The Right to Protection}

It is also the right of the coastal State to take relevant measures to protect national security. This right stems from the relevant draft of The Hague Conference in 1930, which provides that the coastal State may, in order to protect its rights and interests related to the territorial sea, take necessary measures to prevent foreign ships from harming its sovereignty and public interests, and that the right of the coastal State to take such measures is not impeded by the right of passage of foreign ships (art. 5). Although the above provision does not explicitly specify the right of the coastal State to protection, it can be inferred from this provision. Unlike jurisdiction, which is determined primarily through domestic legislation, the right to protection is determined primarily through the relevant provisions of UNCLOS. Reasonable and proper exercise of the right of protection can not only better safeguard the sovereignty and interests of coastal states, but also help ensure the full implementation and practice of jurisdiction (including legislative jurisdiction and judicial jurisdiction). Moreover, the exercise of the right of protection itself is the embodiment of the exercise of state sovereignty by coastal States.

First, a coastal State may suspend innocent passage by foreign vessels under certain circumstances. UNCLOS provides that a coastal State may suspend innocent passage by foreign vessels when it is necessary to protect national security, but this is not without restrictions. Article 25 of UNCLOS stipulates three kinds of restrictions, that is, only temporary suspension, the scope of suspension is a special area of the territorial sea, and such suspension shall not be unfair (discriminatory) to foreign vessels in fact or form. This provision can effectively prevent the "special suspension" of special vessels by coastal States. But in practice, the above provisions of UNCLOS have not been strictly implemented. In the international community, some States have enacted domestic laws to completely prohibit navigation by foreign vessels in their territorial waters, and others have suspended harmless passage by foreign vessels in their territorial waters for long periods of time, which are contrary to the principles of the Convention and international law.

Second, coastal States have the right to designate sea lanes and separate navigation routes within the territorial sea. Article 22 of UNCLOS provides that, when necessary to protect the safety of navigation, coastal States may allow harmless foreign vessels (especially those carrying toxic and dangerous substances or materials) to pass through the designated sea lanes or navigation routes. This right is also subject to certain limitations. UNCLOS requires coastal States to take into account four factors in designating sea lanes and diverging traffic: the recommendations of the relevant international organization (IMO), the customary watercourse, the nature of the particular watercourse, and the density of vessel traffic.

\subsection{The Obligations of Coastal State}

Rights and obligations go hand in hand with each other. Coastal States enjoy the above-mentioned rights under UNCLOS and must also perform their due obligations and responsibilities. In addition to the obligations mentioned above not to obstruct innocent passage of foreign vessels and not to discriminate against foreign vessels, the coastal State also undertakes the obligation to publish relevant information. Article 24 of UNCLOS requires the coastal State to make timely disclosure of any situation in its territorial sea that may 
pose a danger to navigation, and article 25 requires the coastal State to make timely disclosure of any decision to suspend innocent passage. In current international practice, coastal States are obliged to make public hazardous situations, as well as their laws and regulations related to innocent passage, navigational charts and baseline maps of territorial waters.

\section{China and Innocent Passage System}

\subsection{China's Current Position on the Right of Innocent Passage}

With the advancement of science and technology, the deepening of globalization and the increase of maritime power of each country, the international context has become complicated. There is no dispute over whether the innocent passage system applies to merchant ships that are not warships. On the issue of warships, China further clarified its position when ratifying UNCLOS in 1996, re-emphasizing that foreign warships must obtain Prior approval from China or inform China of the relevant situation in advance when they pass through territorial waters. This position is also reflected in many domestic laws of China. In 1958, the Declaration of the Government of the People's Republic of China on China's Territorial Sea stipulates that foreign military vessels and aircraft shall not enter China's territorial sea and its airspace without China's permission. The Contiguous Zone Law of 1992 provides that foreign non-military vessels enjoy the right of innocent passage in China's territorial waters, while military vessels must obtain China's approval (art. 6); In various international conferences, including the Third United Nations Ocean Conference, China has always adhered to this position[3].

China has been under imperialist oppression for a long time in modern times, so China's position on this issue is very firm. In the past, China was weak and unable to compete with the great powers, so its position is relatively conservative. Since the 1940s, China has gradually become a major country and participated in more international affairs. Harmless through a system the birth and development of China's participation, but as the "area" and ocean fate community is put forward, China will inevitably depth fusion, integration with the international economy, we should adjust measures to local conditions, use of advantage a voice on harmlessly through the system, affect the development of the law of the sea, to own the rule of law in our country.

\subsection{Rational Use of the Right of Innocent Passage}

The system of innocent passage is the result of the struggle between the states and various forces of the international community. As the superstructure, it reflects the needs of the states of the international community. Facing the complicated international background, China should make full use of international law to safeguard and strive for national interests.

\subsubsection{Domestic Policy}

At the 18th NATIONAL Congress of the CPC, we put forward the important task of building a maritime power, and at the 19th National Congress, we put forward important measures to speed up the building of a maritime power. This shows that China attaches great importance to the ocean and has a huge demand for it. Therefore, we should make clear what kind of road we should take to become a maritime power and unswervingly advance the strategy of becoming a maritime power based on China's reality and build a maritime system with Chinese characteristics.

Secondly, in the face of the us-led western forces' provocations, China should keep calm and have its own ideas on the issue of innocent passage. It should not refute or respond to their claims in various ways, so as to prevent the development in the direction expected by the US and deviate from the original intention of international law.

Finally, domestic legislation on the Marine system should be strengthened. Although a relatively complete legal system has been formed in China, the legislation on the Marine system in China started late and there are still many problems. China can give full play to its initiative and enthusiasm, constantly improve its domestic maritime legislation, overcome the defects in UNCLOS and take the initiative in the event of disputes.

\subsubsection{External Policy}

First, to develop together with neighboring countries, China can include other neighboring countries in the development plan, take the initiative to embrace other countries, common development, common prosperity, to coordinate relations with neighboring countries on the principle of mutual benefit, cooperation and win-win, eliminate differences and reach consensus.

Second, we must rise peacefully. China is a responsible major country. Today, China is advancing the Belt and Road Initiative, which is not only conducive to China's development, but also to the great rejuvenation of the Chinese nation. It also brings development opportunities and benefits to other countries, which meets the requirements of China's peaceful rise.

By developing a maritime regime, China is not trying to become a maritime hegemon, but to help other developing countries achieve common development while developing itself. Neither a community of shared future for mankind nor a community of shared future for oceans has the slightest ambition to seek hegemony. Instead, we want to join hands with the world for common development and progress.

\section{References}

[1] Jin Yongming, On the system of innocent passage in territorial sea[J]. Studies in International Law, 2016: 65.

[2] Li Hongyun. On the right of innocent passage of foreign warships in territorial waters $[\mathrm{J}]$. Chinese and Foreign Law, 1998: 90-91.

[3] Lu Jiawei. On the right of innocent passage of foreign warships in China's territorial sea[J]. Journal of Yuncheng University, 2016: 47. 